\title{
KDM3A Gene
}

National Cancer Institute

\section{Source}

National Cancer Institute. KDM3A Gene. NCI Thesaurus. Code C134311.

This gene is involved in the negative regulation of histone $\mathrm{H} 3$ methylation. 